\title{
THE IMPACT OF HABIT OF WATCHING MOVIES AND DISCOURSE COMPETENCE ON STUDENTS' SPEAKING SKILL
}

\author{
Emy Puji Lestari, Gunarso Susilohadi, Dewi Sri Wahyuni \\ English Department \\ Teacher Training and Education Faculty \\ Sebelas Maret University
}

Email: emy_puji_lestari@yahoo.com

\begin{abstract}
In the literature, it is stated that there are correlations between 1) students' habit of watching movies and speaking skill; (2) students' discourse competence and speaking skill; and (3) students' habit of watching movies and discourse competence to speaking skill simultaneously. Apparently, this theory is proved by the result of the research which was conducted in May 2013 at SMA Negeri 1 Karanganyar. This article discusses the result of the research. The sample is 30 from the population of 306 eleventh grade students. The instruments to collect the data are in the forms of questionnaire and test. The questionnaire is used to collect the data of students' habit of watching movies while the test is used to collect the data of students' discourse competence and speaking skill. The techniques which are used in analyzing the data are Simple Correlation and Multiple Regression Correlation. The result shows that in the level of significance $\alpha=0.05$, (1) there is a positive correlation between students' habit of watching movies and speaking skill ( $\mathrm{rxly}=0.632$, to $=4.314>\mathrm{tt}=1.7)$; (2) there is a positive correlation between students' discourse competence and speaking skill $(\mathrm{rx} 2 \mathrm{y}=0.567, \mathrm{to}=3.64>\mathrm{tt}=1.7)$, and (3) there is a positive correlation between students' habit of watching movies and discourse competence to speaking skill simultaneously $($ Ry12 $=0.6525$ and Fo $=10.012>\mathrm{Ft}=3.35)$. It means the increase of students' habit of watching movies and discourse competence, either separately or simultaneously, will be followed by the increase of the students' speaking skill.
\end{abstract}

Keywords: habit of watching movies, discourse competence, speaking skill

\section{INTRODUCTION}

The main goal of language education in Indonesia, including English language education, is that the students are able to use language for communication. The students must master four language skills: listening, reading, writing and speaking. "Speaking in a second or foreign language has often been viewed as the most demanding of the four skills" (Bailey and Savage cited in Lazaraton, 2001: 103). It is used for giving information (transactional function) or for maintaining social relationship (interpersonal function). Thus, one's proficiency in English is often measured from his/her speaking skill.

Speaking is "a productive skill which can be directly and empirically observed" (Brown, 2004: 140). Nunan also states that speaking is a productive oral skill which consists of producing systematic verbal utterances in order to convey meaning (cited in Mart, 2012: 91). Similarly, Chaney defines speaking as "the process of building 
and sharing meaning through the use of verbal and non-verbal symbols, in a variety of contexts" (cited in Šolcová, 2011: 17). Thus, speaking skill in this study is defined as productive oral skill which consists of producing systematic verbal utterances in a variety of context to convey meaning.

As a spontaneous activity, speaking often contains reduced forms. Thus, to avoid producing formal-sounding full-forms of English language, the students need authentic materials which can give them model of the real use of English language in communication. One of the authentic materials which can be used as language input is English movie. Even though the utterances which are spoken in the scenes are not spontaneous, the scripts of those utterances are specially made to be uttered, not to be written. Besides, Katchen (2001: 734) notes that movies use "the speed of spoken language delivered for native speakers". So, the conversation is made based on its regular use in real daily life communication. Thus, by having habit of watching English movies, students are exposed to more English language input.

Habit is defined as "an effect of repeated acts and an aptitude to reproduce them" (Dubray, 1910). Thomas and Znaniecki also note that a habit is "the tendency to repeat the same act in similar material conditions" (cited in Hodgson, 2006: 6). In this definition, a habit is appeared when people do almost the same action for the same situation. Similarly, Hodgson (2006: 6) notes that Veblen and other pragmatists philosophers see habit as a proclivity or capacity to use previously acquired behavior or thoughts, triggered by an appropriate stimulus or context. Thus, it can be concluded that habit is a tendency or proclivity to repeat the same act or response which is triggered by appropriate stimulus in similar situation or condition. Further, Uri Dowbenko (n.d: ix), states that "Watching movies is a function of vision, of using one's eyes to consciously and conscientiously absorb information, while being entertained, amused and/or enlightened". Thus, habit of watching movies in this study is defined as a tendency to repeat the activity of using the function of eyes and ears to pay attention to and absorb information from a sequence of images which are presented in illusory motion, while being entertained, amused, and/or enlightened.

But, to improve speaking skill, authentic language input only is not enough; the language input also needs to be comprehensible. The fourth point of Krashen's Input Hypothesis states that "Production ability emerges. It is not taught directly" (1987: 22). Production can be both speaking and writing. Dealing with speaking skill, Krashen further states that "The best way, and perhaps the only way, to teach speaking, according to this view, is simply to provide comprehensible input" (1987 : 22). It can be achieved by simplification and the help of "context, our knowledge of the world, our extra-linguistic information to help us understand language directed at us" (Krashen, 1987: 21). English movie is an example of comprehensible input since it provides context. Thus, by having a habit of watching English movies, the students are exposed to comprehensible input.

Further, Schmidt (2010: 722) in his Noticing Hypothesis argues that "Input does not become intake for language learning unless it is noticed, that is consciously registered". Thus, learners need to notice the conversation in English movie to comprehend information, expressions, idioms, etc. It, in turn, will lead the learners 
to the improvement of their speaking skill. In short, theoretically, students' habit of watching English movies has positive correlation to their speaking skill.

In oral communication, speakers need to have good discourse competence to be able to participate well in a discourse. It is one of the elements of communicative competence. The Council of Europe's Common European Framework of Reference for Language (2001:123) notes that discourse competence is defined as "the ability of a user/learner to arrange sentences in sequences so as to produce coherent stretches of language". Similarly, CelceMurcia (2007: 46) defines discourse competence as "the selection, sequencing, and arrangement of words, structures, and utterances to achieve a unified spoken message". It consists of several sub-areas, in which four most important sub-areas are: (1) cohesion which deals with the use of reference, substitution/ellipsis, conjunction, and lexical chains; (2) deixis which refers to situational grounding achieved through use of personal pronouns, spatial terms, temporal terms, and textual reference; (3) coherence which refers to expressing purpose/intent through appropriate content schemata, managing old and new information, maintaining temporal continuity and other organizational schemata through conventionally recognized means; and (4) generic structure which refers to formal schemata that allow the user to identify an oral discourse segment as a conversation, narrative, interview, etc. (Celce-Murcia, 2007: 47). Thus, discourse competence which is discussed in this study is defined as the selection, sequencing, and arrangement of words, structures, and utterances to achieve a unified spoken message.
In Celce-Murcia's recent model of communicative competence (2007: 45), discourse competence is placed in the central of communicative competence. Linguistic competence, sociocultural competence, formulaic competence and interactional competence come together and shape the discourse competence; while strategic competence allows interlocutors to resolve ambiguities and to compensate for deficiencies in any of the other competences. It implies that discourse competence is the heart of communicative competence which is supported by five other competences. In short, based on the theory, discourse competence and speaking skill have a positive correlation. Further, theoretically, students' habit of watching movies and discourse competence, simultaneously, have positive correlation with students' speaking skill.

The writer had conducted a research to prove the correlational theory above. This article is aimed to report the research result which proves that 1) there is a correlation between students' habit of watching movies and speaking skill; 2) there is a correlation between students' discourse competence and speaking skill; and 3) there is a correlation between students' habit of watching movies and discourse competence to speaking skill simultaneously; as stated in the theory.

Thus, the problems of the research are: 1) Is there a positive significant correlation between habit of watching movies and speaking skill of the eleventh grade students of SMA Negeri 1 Karanganyar in the academic year of 2012/2013?; 2) Is there a positive significant correlation between discourse competence and speaking skill of the eleventh grade students of SMA Negeri 1 Karanganyar in the academic year of 2012/2013?; 3) Is there a positive significant 
correlation between habit of watching movies and discourse competence simultaneously, to speaking skill of the eleventh grade students of SMA Negeri 1 Karanganyar in the academic year of 2012/2013?

\section{RESEARCH METHODS}

The research was conducted in May at SMA Negeri 1 Karanganyar. The sample is 30 from the population of 306 eleventh grade students. The research method used in this research is correlational method. According to Nunan (1992: 38), correlational method estimates the degree of association between two variables. Correlational research investigates the relationship between two or more variables without any attempt to manipulate the variables. In this study, the variables are: habit of watching movies, discourse competence, and speaking skill.

The instruments which are used to collect the data of this study are in the forms of questionnaire and test. Questionnaire is used to get the data of habit of watching movies. It consists of 45 items for the tryout and 30 items for the test. The questionnaire is in Indonesian language with four optional answers: a) sangat setuju, b) setuju, c) tidak setuju, d) sangat tidak setuju. Test is used to get the data of the students' discourse competence and speaking skill. To collect the data of students' discourse competence, the researcher uses multiple choice questions in which each number of questions consists of four options A, B, C, and $\mathrm{D}$ from which the students choose the correct answer. It consists of 30 numbers of multiple choice questions for the try-out, while for testing the samples, it consists of 20 numbers of multiple choice questions. For collecting the data of speaking skill, the researcher uses performance test in which the students perform role play based on certain situation. The students' performance is measured based on two aspects: accuracy and fluency in which accuracy covers pronunciation, grammar, and vocabulary; while fluency deals with "the ability to keep going when speaking spontaneously" (Harmer cited in Vilímec, 2006: 10). For checking the clarity of the instruction of speaking skill, the researcher uses readability test which consists of two questions dealing with the instruction of the test.

The data are, then, analyzed by using Product Moment and Multiple Linear Regression. Product Moment Formula is used to test the first and the second hypotheses which say that there is a positive correlation between habit of watching movies and speaking skill, and there is a positive correlation between discourse competence and speaking skill. The statistical hypothesis for the first hypothesis is $\mathrm{H}_{0}: \mathrm{r}_{\mathrm{x} 1 \mathrm{y}}=0$. It means that there is no correlation between students' habit of watching movies $\left(\mathrm{X}_{1}\right)$ and speaking skill $(\mathrm{Y})$. Then, $\mathrm{H}_{\mathrm{a}}: \mathrm{r}_{\mathrm{x} 1 \mathrm{y}}>0$. It means that there is a positive correlation between students' habit of watching movies $\left(\mathrm{X}_{1}\right)$ and speaking skill (Y). The statistical hypothesis of the second hypothesis is $\mathrm{H}_{0}: r_{x 2 y}=0$. It means that there is no correlation between students' discourse competence $\left(\mathrm{X}_{2}\right)$ and speaking skill $(Y)$. Then, $H_{a}: r_{x 2 y}>0$ means that there is a positive correlation between students' discourse competence $\left(\mathrm{X}_{2}\right)$ and speaking skill (Y).

Multiple Linear Correlation is used to test the third hypothesis which says that there is a positive correlation between habit of watching movies and discourse competence toward speaking skill. The 
statistical hypothesis for the third hypothesis is $\mathrm{H}_{0}: \mathrm{Ry}_{12}=0$. It means that there is no correlation between students' habit of watching movies $\left(\mathrm{X}_{1}\right)$ and discourse competence $\left(\mathrm{X}_{2}\right)$ to speaking skill (Y) simultaneously. Then, Ha: Ry $12>0$ means that there is a positive correlation between students' habit of watching movies and discourse competence to speaking skill simultaneously.

\section{RESEARCH FINDINGS AND DISCUSSIONS}

From the testing of the first hypothesis, it is known that the first hypothesis, saying that there is a positive correlation between habit of watching movies and speaking skill is accepted. The result of the first hypothesis testing computation shows that the correlation coefficient $\left(r_{x 1 y}\right)$ between habit of watching movies $\left(\mathrm{X}_{1}\right)$ and speaking skill $(\mathrm{Y})$ is 0.6319 and after being calculated to the $t$-value, $t_{o}$ (4.314) is higher than $t_{t}(1.70)$ or $\left(t_{o}>t_{t}\right)$. It means that there is a significant, positive correlation between habit of watching movies and speaking skill of the eleventh grade students of SMA Negeri 1 Karanganyar in the academic year of $2012 / 2013$. Then, it also means that the increase of habit of watching movies will be followed by the increase of students' speaking skill. The coefficient determination $\left(\mathrm{r}_{\mathrm{x} 1 \mathrm{y}}{ }^{2}\right)$ between habit of watching movies $\left(\mathrm{X}_{1}\right)$ and speaking skill $(\mathrm{Y})$ is 0.3993. It means that $39.93 \%$ variance of speaking skill (Y) is influenced by habit of watching movies $\left(\mathrm{X}_{1}\right)$ and $60.07 \%$ is influenced by other factors. Thus, based on this research, the theory which states that there is a correlation between students' habit of watching movies and speaking skill is proved.
Speaking is spontaneous action in which "fluent speech contains reduced forms, such as contractions, vowel reduction, and elision; so that learners who are not exposed to or who do not get sufficient practice with reduced speech will retain their rather formal-sounding full forms" (Lazaraton, 2001: 103). Thus, to be able to have a good speaking skill, the students need to be exposed to materials which can give them model of real use of English language in communication. In other words, the students need to be exposed to authentic materials.

According to Bayri (2010: 167), "what is meant by 'authentic language material' are literary works, films, or songs". Thus, English movies can be used as authentic English language input for students. As language input, English movies are comprehensible since movies present dialogues in context. According to Krashen, the best and perhaps the only way to teach speaking is by providing comprehensible input (1987: 22), to which English movies can be used. Further, Schmidt states that input needs to be noticed to become intake for language learning (2010: 722). From noticing the input, the learners can identify and comprehend some expressions or idioms and the way to use them in speaking. If the students have habit of watching English movies, they will have more chance to notice the conversation in English movies as language input. They will have more opportunity to identify and comprehend expressions or idioms from the movies, which, in turn, can be used in practice speaking.

In brief, students' habit of watching movies affects their speaking skill; if the students have a good habit of watching movies, their speaking skill will also be 
good. This correlational theory between habit of watching movies and speaking skill is proved by the research which was done to the eleventh grade students of SMA Negeri 1 Karanganyar in the academic year of 2012/2013.

From the testing of the second hypothesis which says that there is a positive correlation between discourse competence and speaking skill, it is known that the second hypothesis is accepted. The result of the computation shows that the correlation coefficient $\left(\mathrm{r}_{\mathrm{x} 2 \mathrm{y}}\right)$ between discourse competence and speaking skill is 0.5667 and after being calculated to the $t$-value, $t_{0}$ (3.64) is higher than $t_{t}(1.70)$ or $\left(t_{o}>t_{t}\right)$. It means that there is a significant, positive correlation between discourse competence and speaking skill of the eleventh grade students of SMA Negeri 1 Karanganyar in the academic year of $2012 / 2013$. Then, it also means that the increase of discourse competence will be followed by the increase of students' speaking skill. The coefficient determination $\left(\mathrm{r}_{\mathrm{x} 2 \mathrm{y}}{ }^{2}\right)$ between discourse competence $\left(\mathrm{X}_{2}\right)$ and speaking skill $(\mathrm{Y})$ is 0.3212 . It means that $32.12 \%$ variation of speaking skill (Y) is influenced by discourse competence $\left(\mathrm{X}_{2}\right)$ and $67.88 \%$ is influenced by other factors. Thus, based on this research, the theory which states that there is a correlation between students' discourse competence and speaking skill is proved.

Speaking is an oral communication skill which enables person to participate in a discourse. To be able to participate well in a discourse, the students need to have a good discourse competence. According to CelceMurcia (2007: 46), discourse competence is the element which acts as the central of any construct of communicative competence. It consists of four aspects: cohesion, deixis, coherence, and generic structure (Celce-
Murcia, 2007: 47). Having good discourse competence means the speaker can create cohesive and coherent utterances and use appropriate deixis based on certain generic structure, while the listener can interpret the utterances correctly to be coherent with the topic discussed.

Further, Celce-Murcia in her 2007 model of communicative competence explains that discourse competence, as the central of communicative competence, is supported by five competences: sociocultural competence, linguistic competence, formulaic competence, interactional competence, and strategic competence (2007: 46-50). Those competences influence students' discourse competence.

Discourse competence can be differentiated into two: spoken and written. From the research, it is also found that $75 \%$ of contribution of discourse competence on students' speaking skill comes from spoken discourse competence. It happens because spoken discourse competence deals with the students' ability which enables them to communicate well in a spoken discourse, while written discourse competence deals with the students' ability which enables them to communicate well in a written discourse. The dependent variable that is used in this research is speaking skill. Speaking skill is one's oral communication skill which enables them to participate in a discourse. Theoretically, type of discourse which is closer to speaking skill is spoken discourse. In interacting in spoken discourse, the speaker will use spoken discourse competence more than written discourse competence. Thus, spoken discourse competence will contribute on students' speaking skill more than written discourse competence. This theory is proved 
by the result of the research which states that $75 \%$ of contribution of discourse competence on students' speaking skill comes from spoken discourse competence, while another $25 \%$ comes from written discourse competence.

In brief, students discourse competence, especially spoken discourse competence, affects their speaking skill; improvement of discourse competence causes students' speaking skill improves. This correlational theory between discourse competence and speaking skill is proved by the research which was conducted to the eleventh grade students of SMA Negeri 1 Karanganyar in the academic year of 2012/2013.

The third hypothesis which says that there is a positive correlation between habit of watching movies and discourse competence simultaneously to speaking skill is accepted. The result of the computation shows that the correlation coefficient $\left(\mathrm{R}_{\mathrm{y} 12}\right)$ is 0.6525 . After being calculated to the Fvalue, the value of $F_{o}(10.012)>F_{t}(3.35)$. It means that there is a significant, positive correlation between habit of watching movies and discourse competence simultaneously and speaking skill of the eleventh grade students of SMA Negeri 1 Karanganyar in the academic year of $2012 / 2013$. Then, it also means that the increase of habit of watching movies and discourse competence will be followed by the increase of students' speaking skill. The result also shows that habit of watching movies and discourse competence have a positive correlation with speaking skill either separately or simultaneously.

The determination coefficient $\left(\mathrm{r}_{\mathrm{x} 1 \mathrm{y}}^{2}\right)$ between habit of watching movies and speaking skill is 0.3993, while the determination coefficient of discourse competence and speaking skill is 0.3212 . It means that separately the two variables correlate to speaking skill significantly. Simultaneously, those two variables also correlate to speaking skill significantly. It can be seen from the determination coefficient $\left(\mathrm{R}^{2}\right)$ of correlation between habit of watching movies and discourse competence toward speaking skill which shows 0.4258 . It means that $42.58 \%$ variance of speaking skill is determined by habit of watching movies and discourse competence and $57.42 \%$ variance of speaking skill is determined by other factors. Thus, based on this research, the theory which states that there is a correlation between students' habit of watching movies and discourse competence to speaking skill simultaneously is proved.

By having habit of watching English movies, the students have more opportunity to be exposed to authentic materials which show the use of English in real communication in English speaking countries. Moreno Jaén and Pérez Basanta (2009: 289) reveal that film has authenticity since film "can be replicas of real-life people and real-life situations, and utilize real-life language". English movie shows the use of English in real life context rather than artificial situation, completed with slang, reduced speech, stress, accent, and dialects. But, to improve speaking skill, authentic language input only is not enough; the language input also needs to be comprehensible. English movie is an example of comprehensible input since it provides context on its scene. Thus, by having a habit of watching English movies, it means the students are exposed to lots of comprehensible input.

To improve their speaking skill, the students should notice the conversation in 
English movies. It is in line with Schmidt's Noticing Hypothesis (2010: 722) which argues that "Input does not become intake for language learning unless it is noticed, that is consciously registered". That way, they can identify and comprehend expressions, idioms, or information from the movies. What they get from noticing English movies can be used in practice speaking.

In oral communication skill, speaker also needs to have a good discourse competence to be able to participate well in a discourse. According to Celce-Murcia (2007: 46), discourse competence is the element which acts as the central of any construct of communicative competence. It consists of four aspects: cohesion, deixis, coherence, and generic structure (CelceMurcia, 2007: 47). It is needed in communication both for conveying and interpreting message to be coherent with the topic. It acts as the most important element of communicative competence, while other elements act as supporting competences for discourse competence. Those supporting competences are sociocultural competence, linguistic competence, formulaic competence, interactional competence, and strategic competence (Celce-Murcia, 2007: 46-50). They influence students' discourse competence on their own portion.

In short, improvement of students' habit of watching movies and discourse competence simultaneously causes speaking skill improves. This correlational theory is proved by the research which was done to the eleventh grade students of SMA Negeri 1 Karanganyar in the academic year of 2012/2013.

\section{CONCLUSIONS AND SUGGESTIONS}

From the result of the research, the writer draws some conclusions. First, the theory which states that students' habit of watching English movies has a positive correlation and contribution to their speaking skill is proved. The result shows that $\left(r_{x 1 y}\right)$ is $0.6319, t_{0}(4.314)>t_{t}(1.70)$. It means that the increase of habit of watching movies will be followed by the increase of speaking skill. It also means that the students' habit of watching movies has contribution to their speaking skill. The coefficient determination $\left(\mathrm{r}_{\mathrm{x} 1 \mathrm{y}}{ }^{2}\right)$ is 0.3993 . It means that $39.93 \%$ variation of speaking skill (Y) is influenced by habit of watching movies $\left(\mathrm{X}_{1}\right)$ and $60.07 \%$ is influenced by other factors.

Second, the theory which states that students' discourse competence has a positive correlation and contribution to their speaking skill is proved. The result shows that $\left(r_{x 2 y}\right)$ is $0.5667, t_{o}(3.64)>t_{t}(1.70)$. It means that the increase of discourse competence will be followed by the increase of speaking skill. It also means that the students' discourse competence has contribution to their speaking skill. The coefficient determination $\left(\mathrm{r}_{\mathrm{x} 2 \mathrm{y}}{ }^{2}\right)$ is 0.3212 . It means that $32.12 \%$ variation of speaking skill (Y) is influenced by discourse competence $\left(\mathrm{X}_{2}\right)$ and $67.88 \%$ is influenced by other factors. Further, from the computation, it is found that $75 \%$ of contribution of discourse competence on students' speaking skill comes from spoken discourse competence. It means spoken discourse compentence contributes on students' speaking skill more than written discourse competence.

Third, the theory which states that students' habit of watching English movies and discourse competence simultaneously, 
have a positive correlation and contribution to their speaking skill is proved. The result, $\left(R_{y 12}\right)$ is 0.6525 , Fo (10.012) > Ft (3.35). It means that the increase of habit of watching movies and discourse competence simultaneously will be followed by the increase of speaking skill. The coefficient determination $\left(\mathrm{R}_{\mathrm{y} 12}{ }^{2}\right)$ is 0.4258 . It means that $42.58 \%$ variance of speaking skill (Y) is determined by habit of watching movies $\left(\mathrm{X}_{1}\right)$ and discourse competence $\left(\mathrm{X}_{2}\right)$, and $57.42 \%$ is determined by other factors.

Thus, as the implication of the research, watching English movies habit and discourse competence can be utilized to enhance students' speaking skill. Teachers should erase the assumption that movies cannot provide anything for English language learning. Thus, the teachers should give the students more opportunity to be exposed to authentic language inputs which, in this case, are English movies. The teacher can give them task which makes the students notice the conversation in English movies, for example asks the students to find information and expressions from the movie. The teacher also can ask the students to pay attention to the discourse competence aspects which are presented in the movies. While the students themselves should build awareness for growing a habit of watching English movies and paying attention to the spoken discourse in the movies, such as the way to conduct turntaking which sounds natural and coherent, the use of expressions for certain intention in particular situation, the way to manage the ideas, etc.

\section{BIBLIOGRAPHY}

Bayri, Gaye. (2010). The student perception of visual arts in the speaking classroom. International Journal of
Arts and Sciences, 3(11), 166-180. Retrieved from InternationalJournal.org

Brown, H. D. (2004). Language assessment: principles and classroom practices. White Plains, NY: Pearson Education.

Celce-Murcia, M. (2007). Chapter 3. Rethinking the role of communicative competence in language teaching. In E. A. Soler \& M. P. S. Jordà (Eds.), Intercultural language use and language learning (pp. 41-57). Retrieved from http://elechina.super-red.es/celcemurcia.pdf

Council of Europe. (2001). Common European Framework of Reference for Languages. Retrieved from http://www.coe.int/t/dg4/linguistic/ source/framework_en.pdf

Dowbenko, Uri. (n.d). Hoodwinked: Watching Movies with Eyes Wide Open. Retrieved from http://www.BookFi.org

Dubray, C. (1910). Habit. In The Catholic Encyclopedia. New York: Robert Appleton Company. Retrieved March 7, 2013, from New Advent: http://www.newadvent.org/cathen/0 7099b.htm

Hodgson, G. M. (2006). What are institutions?. Journal of Economic Issues, XL(1), 1-25. Retrieved from http://www.geoffreyhodgson.info/user/image/whatarein stitutions.pdf

Katchen, J., Fox, T., Lin, L. Y., \& Chun, V. (2001). Developments in digital 
video. Colloquium Presented at the

Third Pan-Asian Conference "2001: A Language Odyssey", November 22-25, 2001, Kitakyushu, Japan. Retrieved from http://jaltpublications.org/archive/proceeding s/2001/731.pdf

Krashen, Stephen D. (1987). Principles and practice in second language acquisition. Hertfordshire: Prentice Hall Europe.

Lazaraton, Anne. (2001). Unit II B. Teaching oral skills. In M. CelceMurcia (Eds.), Teaching English as a second or foreign language (pp. 103-115). United States of America: Thomson Learning, Inc.

Mart, Ç. T. (2012). Developing speaking skills through reading. International Journal of English Linguistics, 2(6), 91-96. doi: 10.5539/ijel.v2n6p91

Moreno Jae'n, M and Pe'rez Basanta, C. (2009). Developing conversational competence through language awareness and multimodality: the use of DVDs. ReCALL, 21(3), 283301. doi: $10.1017 / \mathrm{S} 0958344009990036$

Nunan. D. (1992). Research Methods in Language Learning. Cambridge: Cambridge University Press.

Schmidt, Richard. (2010). Attention, awareness, and individual differences in language learning. In W. M. Chan, S. Chi, K. N. Cin, J. Istanto, M. Nagami, J. W. Sew, T. Suthiwan, \& I. Walker, Proceedings of CLaSIC 2010, Singapore, December 2-4 (p. 721737). Retrieved from
http://nflrc.hawaii.edu/PDFs/SCH MIDT\%20Attention,\%20awareness ,\%20and $\% 20$ individual\%20differen ces.pdf

Šolcová, Bc. P. (2011). Teaching speaking skills (Master's diploma thesis, Masaryk University, 2011). Retrieved from http://is.muni.cz/th/329367/ff_m/

Vilímec, E. (2006). Developing speaking skills (Thesis, Pardubice University, 2006). Retrieved from http://dspace.upce.cz/bitstream/101 95/21610/1/D16159.pdf 